УДК 338.43

Людмила Шостак, кандидат економічних наук, доцент, Східносвропейський національний університет імені Лесі Українки, кафедра економіки, безпеки та інноваційної діяльності підприємства,

м. Луцьк; ORCID ID 0000-0001-8786-9582, e-mail: Shostak.Lyudmyla@ eenu.edu.ua

Олена Сосовська, студентка,

Східноєвропейський національний університет імені Лесі Українки, кафедра економіки, безпеки та інноваційної діяльності підприємства, м. Луцьк; ORCID ID 0000-0001-6367-0392 e-mail: Olenasosovska@gmail.com

https://doi.org/10.29038/2411-4014-2020-02-130-136

\title{
ПРОБЛЕМИ КОРПОРАТИВНОГО УПРАВЛІННЯ НА ВІТЧИЗНЯНИХ ПІДПРИЕМСТВАХ
}

У статті розглянуті стан та тенденції розвитку корпоративного управління на вітчизняних підприємствах у порівнянні з іноземними, виявлено проблеми та запропоновано можливі шляхи підвищення ефективності. Вивчено вітчизняну модель корпоративного управління, проаналізовано її переваги та недоліки, узагальнено результативність іiі використання у національній економіці. Проведено діагностику корпоративного управління окремих вітчизняних корпорацій та визначено перспективи їх подальшого розвитку саме при підвищенні ефективності їх корпоративного управління.

Ключові слова: управління, корпоративне управління, корпорація, корпоративний сектор.

Людмила Шостак, кандидат экономических наук, доцент,

Восточноевропейский национальный университет имени Леси Украинки, кафедра экономики, безопасности и инновационной деятельности предприятия, г. Луцк

Елена Сосовська, студентка,

Восточноевропейский национальный университет имени Леси Украинки, кафедра экономики, безопасности и инновационной деятельности предприятия, г. Луцк

\section{ПРОБЛЕМЫ КОРПОРАТИВНОГО УПРАВЛЕНИЯ НА ОТЕЧЕСТВЕННЫХ ПРЕДПРИЯТИЯХ}

В статье рассмотрены состояние и тенденции развития корпоративного управления на отечественных предприятиях в сравнении с иностранными, определено проблемы и предложены возможные пути повышения эфективности. Проанализировано отечественную модель корпоративного управления, проведена діагностика её преимуществ и недостатков, обособлено результативность её использования в национальной экономике. Проведено діагностику корпоративного управления отдельных отечественных корпорацій и определено перспективы их подальшего развития именно при повышении уровня эфективности корпоративного управления.

Ключевые слова: управление, корпоративное управление, корпорация, корпоративный сектор.

Liudmyla Shostak, PhD in Economics, Associate Professor, Lesya Ukrainka Eastern Europen National University, 
Olena Sosovska, Student,

Lesya Ukrainka Eastern Europen National University,

Department of Enterprise Economics, Security and Innovative Activities,

Lutsk

\section{PROBLEMS OF CORPORATE GOVERNANCE AT DOMESTIC ENTERPRISES}

The article discusses the status and development trends of corporate governance at domestic enterprises in comparison with foreign ones, identifies problems and suggests possible ways to improve efficiency. The domestic model of corporate governance is analyzed, the diagnosis of its advantages and disadvantages is carried out, the effectiveness of its use in the national economy is isolated. The corporate governance diagnostics of individual domestic corporations was carried out and the prospects for their further development were determined precisely with an increase in the level of corporate governance efficiency.

There is no single, generally accepted model of corporate governance that would be used by all countries. However, there are certain defined principles, standards, basic criteria and provisions. The Ukrainian model of corporate governance, in contrast to countries with developed market economies, was formed mainly artificially - by almost simultaneous corporatization and privatization of a huge number of state-owned enterprises. The process of formation of corporate relations in Ukraine was somewhat different from the world and has already passed three stages. The effectiveness of corporate governance is defined as the result of a combination of four factors: features of national legislation, type of ownership, governing bodies, social pressure. The main problems of modern corporate governance, in our opinion, are: the uncertainty of the external environment, the difficulty in using the domestic model of corporate governance, violations of shareholder rights.

The transition to a market economy, rapid processes of restructuring and privatization of certain sectors of the national economy have introduced into economic circulation a rather complex category as "corporate governance", which has become the key to successful management of any business unit. Today, the creation of new corporate enterprises is becoming increasingly popular, which in most cases is manifested in the creation of joint stock companies. The effectiveness of their work directly depends on the qualifications of staff, including management, the ability to make and implement decisions, the right management system and so on. The effectiveness of corporate governance is a crucial factor in the success of any company. The problem of the effectiveness of corporate governance is becoming increasingly important in times of economic and political crises, in the period of outflow of qualified personnel, in periods of stagnation of some and the rise of other sectors of the national economy.

Today, corporate governance at Ukrainian enterprises is accompanied by many problems that need to be addressed immediately. The main ones are the lack of a single methodology for assessing the effectiveness of corporate governance, unregulated corporate relations. Therefore, it is necessary to develop a method of corporate governance that would take into account all the problems and peculiarities of the functioning of domestic enterprises and meet the needs of stakeholders in corporate relations.

Key words: management, corporate governance, corporation, corporate sector.

Постановка проблеми та їі значення. Перехід до ринкової економіки, стрімкі процеси реструктуризації а приватизації окремих галузей національної економіки внесли в економічний обіг досить складну категорію як «корпоративне управління», що стало запорукою успішного управління будь-якою господарською одиницею. Сьогодні все більшої популярності набуває створення нових корпоративних утворень, що у більшості випадків проявляється у створенні акціонерних товариств. Ефективність їх функціонування напряму залежить від кваліфікації персоналу, зокрема управлінського,від вміння приймати та реалізовувати рішення, від правильно вибраної системи управління тощо. Ефективність корпоративного управління $є$ вирішальним фактором успішної роботи будь-якої компанії. Проблема ефективності корпоративного управління набуває все більшого значення в період економічних та політичних криз, в часи відтоку кваліфікованого персоналу, в періоди застою одних та піднесення інших галузей національної економіки.

На сьогодні корпоративне управління на українських підприємствах супроводжується багатьма проблемами, які потребують негайного вирішення. Головними 3 них є відсутність єдиної методики оцінки ефективності корпоративного управління, нерегульованість корпоративних відносин. Отже, 
потрібно розробити таку методику такого корпоративного управління, яка врахувала б всі проблеми та особливості функціонування вітчизняних підприємств та задовольнити потреби зацікавлених суб'єктів корпоративних відносин.

Аналіз останніх досліджень. Питанням корпоративного управління присвячені праці багатьох вітчизняних та провідних зарубіжних вчених. Варто відмітити праці таких вчених, як Анісімов О., Білорус О., Винслов Ю., Девіс С., Демб А., Довгань Л., Козаченко Г., Ларіна Р., Мілявський М., Найбаер Ф., Салівен Дж. Тощо. Проте, дане питання вимагає подальших досліджень у зв'язку зі зміною економіко-політичної ситуації в країні, змінюється нормативно-правове забезпечення i відповідно динамічність самої економічної науки вимагає постійного удосконалення та доповнення попередніх досліджень.

Мета і завдання статті. Дослідити основні проблеми, пов'язані з проблемністю корпоративного управління на вітчизняних підприємствах та запропонувати можливі шляхи їх вирішення.

Виклад основного матеріалу. Проблеми корпоративного сектору вітчизняної економіки розглядались вченими в різних аспектах - правовому, організаційному, економічному, фінансовому, інформаційному тощо. Саме таке комплексне вивчення проблеми дало можливість провести всесторонню та повну оцінку корпоративного управління будь-якого підприємства чи корпорації.

Багатьма авторами система корпоративного управління розглядається як організаційна модель, за допомогою якої представляються і захищаються інтереси інвесторів, тобто корпоративне управління $є$ організаційною угодою, яка може охоплювати різні аспекти діяльності корпорації організацію роботи вищих керівних органів, систему мотивації персоналу та інші, і обумовлена розмежуванням права власності від процесу управління. Основною проблемою даного процесу управління $\epsilon$ створення механізмів щодо контролю аутсайдерів (кредиторів та міноритарних акціонерів) за інсайдерами (вищим керівництвом та акціонерами 3 контрольним пакетом акцій). Деякі вчені ототожнюють корпоративне управління з управлінням акціонерного товариства. [1, с.46; 20]

Однієї, загальноприйнятої моделі корпоративного управління, яку б використовували всі країни немає. Проте, існують певні визначені принципи, стандарти, основні критерії та положення, що використовуються в попередньо згаданих контекстах дослідження. Відповідно, практично всі рейтингові агентства використовують для оцінювання рівня корпоративного управління ті стандарти, які запропоновані в цих моделях.

Варто зазначити, що більшість вітчизняних підприємств використовують вітчизняну модель корпоративного управління.

Українська модель корпоративного управління, на відміну від країн з розвиненою ринковою економікою, формувалася переважно штучно - шляхом майже одночасної корпоратизації та приватизації величезної кількості державних підприємств, первісно утворених за умови адмінстративного регулювання економіки. Однак в сучасних умовах масове акціонування підприємств не призвело до істотних зрушень у досягненні основних цілей суспільства. Початковий етап рикової трансформації адміністративно-командної економіки виявив значну невідповідність початкових задумів реформаторів і фактично досягнутих результатів. Отже, підсумки приватизації не дають підстав стверджувати, що основна проблема реформи - формування ефективної структури власності - близька до успішного вирішення.

Процес становлення корпоративних відносин в Україні дещо відрізнявся від світових і на даний час вже пройшов три етапи:

1) Перший етап (1991-1993рр.): прийнято базові закони, у тому числі "Про підприємства в Україні" від 27 березня 1991 року, "Про господарські товариства" від 19 вересня 1991 року, пакет законів про приватизацію, внесено деякі зміни у Цивільний кодекс та Кодекс законів про працю тощо;

2) Другий етап (1993-1997рр.): характеризується масовою приватизацією, оскільки вона відбувался у формі масового акціонування державних підприємств та залучення великої кількості населення до приватизаційного процесу. Приватизація великих і середніх державних підприємств здійснювалась переважно через продаж акцій відкритих акціонерних товариств, створених на базі майна цих об'єктів. Масова приватизація в Україні мала на меті формування не тільки корпоративного сектора, а й фондового ринку та його інфраструктури. Специфіка даного етапу 
визначила і його назву - "сертифікатна" приватизація, оскільки іiі основою стали приватизаційні майнові та компенсаційні сертифікати, а також акції пільгового розміщення. На цьому етапі головними учасниками корпоратизації стали працівники підприємств та їх керівництво, які користувалися значними пріоритетами під час купівлі акцій. Результатом став безпрецедентний за масштабами розподіл акцій серед дрібних власників, що дозволило дослідникам на даному етапі констатувати формування "аутсайдерської" моделі корпоративного управління;

3) Третій етап (розпочався у грудні 1997 р.): характеризується опрацюванням та внесенням суттєвих змін до Закону "Про господарські товариства". За цей період на розгляд Верховної ради внесено закони проектів "Про акціонерні товариства", "Про корпоратизацію", прийнято новий Цивільний кодекс під гаслом створення ефективних механізмів оптимізації структури власності, що зумовило пошук нових схем іï формування. Відбувався продаж великих державних об'єктів та активне залученням до приватизаційних процесів зовнішніх інвесторів. Основною відмінністю цього етапу стало проведення продажу акцій за грошові кошти у вигляді комерційних і некомерційних конкурсів, грошових аукціонів та продажу пакетів акцій на фондових біржах.

Отже, бачимо, що процес становлення вітчизняної системи (моделі) корпоративного управління $\epsilon$ довготривалий і затяжний. Відповідно досить важко говорити про визначення ефективності корпоративного управління на вітчизняних підприємствах.

Ефективність корпоративного управління визначають як результат поєднання чотирьох факторів, які застосовують відповідно до національної або регіональної специфіки: особливості національного законодавства, тип власності, органи управління, суспільний тиск. Вивчаючи їх, можна досягнути глибшого розуміння національного «регуляційного» середовища, 3 яким взаємодіють корпорації [2].

Однозначно, що на ефективність корпоративного управління будь-якого підприємства впливають зміни як внутрішнього, так і зовнішнього середовища функціонування підприємства. Тому варто розглянути проблеми здійснення корпоративного управління як на внутрішньому, так $\mathrm{i}$ на зовнішньому рівнях.

На внутрішньому рівні проблеми ефективності корпоративного управління, пов'язані 3 відсутністю на підприємствах розвиненої корпоративної культури, непорозумінням у відносинах між акціонерами (власниками) та управляючими (менеджерами); нерозуміння ролі корпоративного секретаря, конфліктні ситуації, недотримання кодексу «корпоративного управління» тощо. Проте ці проблеми виникають і зникають під впливом самого підприємства, тобто його структури управління і вирішуються всередині підприємства чи корпорації.

Щодо зовнішніх проблем слід відмітити, що структура власності корпоративних підприємств створювалася, в основному, не класичним шляхом об'єднання капіталів, а шляхом розподілу статутних фондів державних підприємств під час приватизації. При цьому, оскільки значних масштабів набула сертифікатна (безплатна) приватизація, то підприємства не отримали реальних інвестицій, що зумовило неприйняття управлінським персоналом акціонерів як власників. Особливості формування вітчизняного корпоративного сектора: сильно розпорошена, неефективна структура акціонерної власності в процесі приватизації; значна роль держави у формуванні корпоративного сектора; наявність у держави великої кількості акцій і необхідність розв'язання проблеми управління державними корпоративними правами; потужне податкове навантаження, яке створює для акціонерів різних галузей неоднакові податкові умови тощо. [3, с. 80]. Причому виникнення цього сегмента проблем ніяким чином не пов'язане із недосконалістю чи неефективністю системи управління на конкретному підприємстві, а виникає в силу обставин, які не залежать від підприємства і не можуть мати ніякого впливу з боку системи корпоративного управління.

Особливостями формування ефективного вітчизняного корпоративного сектора є: сильно розпорошена, неефективна структура акціонерної власності в процесі приватизації; значна роль держави у формуванні корпоративного сектора; наявність у держави великої кількості акцій i необхідність розв'язання проблеми управління державними корпоративними правами; потужне податкове навантаження, яке створює для акціонерів різних галузей неоднакові податкові умови тощо.

Основними проблемами сучасного корпоративного управління, на нашу думку, є наступні: 
- невизначеність зовнішнього середовища, в якому функціонують учасники корпоративного управління (корпорації) . зовнішнє середовище вітчизняної економіки й надалі залишається невизначеним, складним, досить проблемним, причому із значною кількістю яскраво виражених неринкових ознак;

- складність у використанні вітчизняної моделі корпоративного управління, що призводить до значних помилок та прорахунків, і як результат - неефективність системи управління вцілому;

- порушення, що стосуються прав акціонерів, інформованості стосовно дивідендів, прозорості окремих видів діяльності та господарських операцій, нерегулярне та неповне інформування акціонерів, непрозорість та недоступність до фінансово-економічної інформації;

- неефективні рішення менеджерів, внаслідок їх недостатньої кваліфікації чи обізнаності і як наслідок - зниження вартості акцій, доходів корпорації та дивідендів акціонерів;

- небажання менеджерами окремих корпорацій використовувати в повній мірі Кодекс корпоративного управління;

- різке розходження теорії та практики стосовно корпоративного управління, його принципів, методик прийняття рішень розподілу доходів тощо.

Причому, в останні місяці, в період тотального карантину, обмеження діяльності окремих корпорацій та підприємств проблемних питань стає все більше, а ресурси для їх швидкого та ефективного вирішення практично відсутні.

Звичайно, що вирішення окреслених проблем одномоментно не відбудеться, хоча поступове їх вирішення обов'язково призведе до покращення ефективності корпоративного управління на вітчизняних підприємствах.

На нашу думку, вирішення окреслених проблем варто здійснювати наступним чином і в такій послідовності:

1. Узгодження на законодавчому рівні інтересів усіх сторін корпоративного управління, а також чітко закріплена законодавчо процедура виплати дивідендів акціонерів усіх рівнів.

2. Зрозуміло, що регламентація виплати дивідендів призведуть до притоку інвестицій як з боку населення, так і іноземних, що значно пожвавить фондовий ринок та стан вітчизняної економіки вцілому.

3. Вдосконалення управління (конкретними організаціями) з поступовим переходом на засади корпоративного управління.

4. Використання гнучкої системи пільгового оподаткування дивідендів 3 метою залучення інвестицій в цінні папери корпорацій.

5. Усунення білих плям в теорії щодо корпоративного управління в Україні, що ускладнює практику корпоративних відносин.

6. Розробка заходів та практичних рекомендацій щодо усунення проблем у практиці корпоративного управління в Україні, оскільки це не дозволяє залучати більшості вітчизняних акціонерних товариств ресурси інвесторів i обмежує джерела фінансування їх фінансово господарської діяльності, що негативно відбивається як на їх діяльності та і на розвитку економіки України в посткризовий період.

7. Більшість великих підприємств повинні зрозуміти необхідність використання на практиці корпоративного управління, оскільки це дасть їм наступні можливості:

- вихід на європейський та світовий ринки й необхідність посилення власних конкурентних переваг;

- приєднання до угод міжнародного економічного співтовариства й важливість відтворення власної ідентичності та конкурентного потенціалу;

- покращання інвестиційного клімату та надання гарантій інвесторам, збільшення інноваційноінвестиційної діяльності;

- ефективне використання корпоративних прав 3 метою підвищення ефективності енерго- та ресурсокористування, виробництва та його модернізації, обсягів експортно-імпортних операцій [4, с. 147].

Зрозуміло, що на сучасному етапі розвитку корпоративного управління в Україні лише серйозні зміни податкового законодавства та чітка регламентація порядку нарахування і виплати дивідендів 
призведуть до притоку інвестицій в економіку як з боку населення, так і з боку іноземних інвесторів [5, c. 244].

Висновки і перспективи подальшого дослідження. На сьогодні можна стверджувати, що в Україні вітчизняна модель корпоративного управління перебуває на етапі свого активного становлення й розвитку.

Для кращої роботи акціонерних товариств пропонується приділити особливу увагу:

1. Корпоративним відносинам. Для цього потрібно застосувати методи і засоби державного регулювання. Це потрібно для того щоб держава перетворилась 3 простого власника акцій в активного акціонера.

2. Вдосконаленню законодавчої бази. Внесення змін до Закону України "Про акціонерні товариства". Це дасть змогу покращити роботу акціонерних товариств.

3. Покращенню корпоративної культури в товаристві, зокрема додержання прав акціонерів.

4. Підвищенню конкурентоздатності фондового ринку України та вихід на іноземні ринки.

5. Підвищенню інвестиційної привабливості акціонерних товариств, зокрема за допомогою оптимізації дивідендної політики та покращення інформаційної прозорості товариства.

6. Запровадженню на акціонерному товаристві головних принципів корпоратиного управління та обгрунтування ролі корпоративного секретаря в роботі акціонерного товариства.

Таким чином, 3 метою подальшого удосконалення української моделі корпоративного управління доцільно враховувати світовий досвід управління, адаптувавши його до національних економічних умов. Подальші дослідження необхідно спрямовувати на питання, пов'язані 3 підвищенням зацікавленості вітчизняних корпорацій у створенні ефективної структури корпоративного управління використовуючи існуючі досягнення.

У подальших дослідженнях автор планує більш детально зупинитись на проблемі визначення ефективності корпоративного управління вітчизняних корпорацій з практичної точки зору.

\section{Джерела та література}

1. Бабіченко В.В. Актуальні проблеми корпоративного управління в Україні та шляхи їх вирішення . Науково-виробничий журнал «Інновачійна економіка». 2014. №4. С. 46-50.

2. Боковець В.В. Ефективність корпоративного управління на підприємствах. Глобальні та національні проблеми економіки. 2015. №8.С. 328-331

3. Коробка С.В. Корпоративне управління в Україні: проблеми та шляхи їх вирішення. Науковий вісник ЛНУВМБТ імені С.3.Гжииького. 2016. № 2. С. 80-83.

4. Кривець Ю.М. Проблеми та перспективи розвитку корпоративного управління агроформувань. URL: https://www.pdaa.edu.ua/sites/default/files/nppdaa/11/23.pdf.

5. Войцеховська Ю. В. Проблеми корпоративного управління в Україні та шляхи їх вирішення . «Львів. політехніка». 2009. С. 244-247.

6. Окунєв О. Корпоративне управління як новий тренд українських компаній URL: http://yurgazeta.com/publications/events/korporativne-upravlinnya-yak

7. Козакова Т.С. Сучасні підходи до визначення корпоративного управління в умовах інформаційної економіки. Причорноморські економічні студіi. 2016. № 1. С. 56-58.

\section{References}

1. Babichenko V.V. (2014), Aktualni problemy korporatyvnoho upravlinnia v Ukraini ta shliakhy yikh vyrishennia . Naukovo-vyrobnychyi zhurnal «Innovatsiina ekonomika» [Actual problems of corporate governance in Ukraine and ways to solve them], Naukovo-vyrobnychyj zhurnal «Innovatsijna ekonomika», vol. 4, pp. 46-50. [in Ukrainian].

2. Bokovets V.V. (2015), Efektyvnist korporatyvnoho upravlinnia na pidpryiemstvakh. Hlobalni ta natsionalni problemy ekonomiky. [The effectiveness of corporate governance in enterprises. Global and national economic problems], vol. 8, pp. 328-331. [in Ukrainian].

3. Korobka S.V. (2016), Korporatyvne upravlinnia v Ukraini: problemy ta shliakhy yikh vyrishennia [Corporate governance in Ukraine: the problems and ways of their solution], Naukovyj visnyk LNUVMBT imeni S.Z.Yzhyts'koho, vol. 2, pp. 80-83. [in Ukrainian]. 
4. Krivets Yu.M. Problemy ta perspektyvy rozvytku korporatyvnoho upravlinnia ahroformuvan. [Problems and prospects of development of corporate management of agricultural formations]. Retrieved from: https://www.pdaa.edu.ua/sites/default/files/nppdaa/11/23.pdf [in Ukrainian].

5. Vojtsekhovs'ka Yu. V. (2009), Problemy korporatyvnoho upravlinnia v Ukraini ta shliakhy yikh vyrishennia ["Problems of corporate governance in Ukraine and ways to solve them"], vol. 1, pp. 244-247. [in Ukrainian].

6. Okunev O. Korporatyvne upravlinnia yak novyi trend ukrainskykh kompanii. [Corporate governance as a new trend of Ukrainian companies]. Retrieved from: http://yur-gazeta.com/publications/events/korporativne-upravlinnyayak [in Ukrainian].

7. Kozakova T.S. (2016), Suchasni pidkhody do vyznachennia korporatyvnoho upravlinnia v umovakh informatsiinoi ekonomiky. [Modern approaches to the definition of corporate governance in the information economy]. Black Sea Economic Studies. vol. 1, pp. 56-58. [in Ukrainian].

Стаття надійшла до редакції 20.05.2020 р. 